\title{
TEMPERATURE MEASUREMENT BEHIND SELF-SUSTAINING JET ENGINE OF A GLIDER
}

\author{
J. Matějü *
}

\begin{abstract}
Analysis of temperature field behind a small jet engine TBS400N-TJ42 was necessary for finding the maximum temperature of exhaust gases mainly at a glider tail position. Results can be useful for validating simulation tool. A low cost 1-axis manual traverse system with $9 \mathrm{~K}$-type thermocouples was made for this purpose. The maximum temperature at the tail position was less than $83{ }^{\circ} \mathrm{C} \pm 2.5^{\circ} \mathrm{C}$ during static tests. Many HpH flight tests showed maximum temperature of $65{ }^{\circ} \mathrm{C}$ on the tail of an aircraft. The composite tail technology of production was modified for higher temperature endurance.
\end{abstract}

Keywords: jet engine, exhaust gases temperature, glider, thermocouple

\section{Introduction}

A glider is an aircraft typically without any engine, that can fly even more than thousand kilometres long distances thankful thermal streams in atmosphere. The thermal streams are not easy to find and the weather can change very fast to be unusable for a long flight. If an airfield is far away in bad weather, terrain landing is unavoidable. This can be dangerous mainly for the extreme long wing-span gliders. A self-sustaining jet engine can provide necessary thrust for flying back to the airfield. The gliders are mainly made of composite material, that is not usually temperature resistant. Analysis of temperature field behind jet engine TBS400N-TJ42 (see tab. 1, fig. 1) was necessary for finding the temperature of exhaust gases mainly at the tail position of the glider HpH $304 \mathrm{~S}$ JET (fig. 2).

Tab. 1: Technical parameters of TBS400N-TJ42

\begin{tabular}{lllc}
\hline Diameter & $156 \mathrm{~mm}$ & IDLE revolutions & $30000 \mathrm{rpm}$ \\
\hline Length & $320 \mathrm{~mm}$ & Maximum revolutions & $97000 \mathrm{rpm}$ \\
\hline Weight & $4 \mathrm{~kg}$ & Thrust at $100 \% \mathrm{rpm}$ & $400 \mathrm{~N}$ \\
\hline Compressor & 1 stage radial & Turbine & 1 stage axial \\
\hline
\end{tabular}

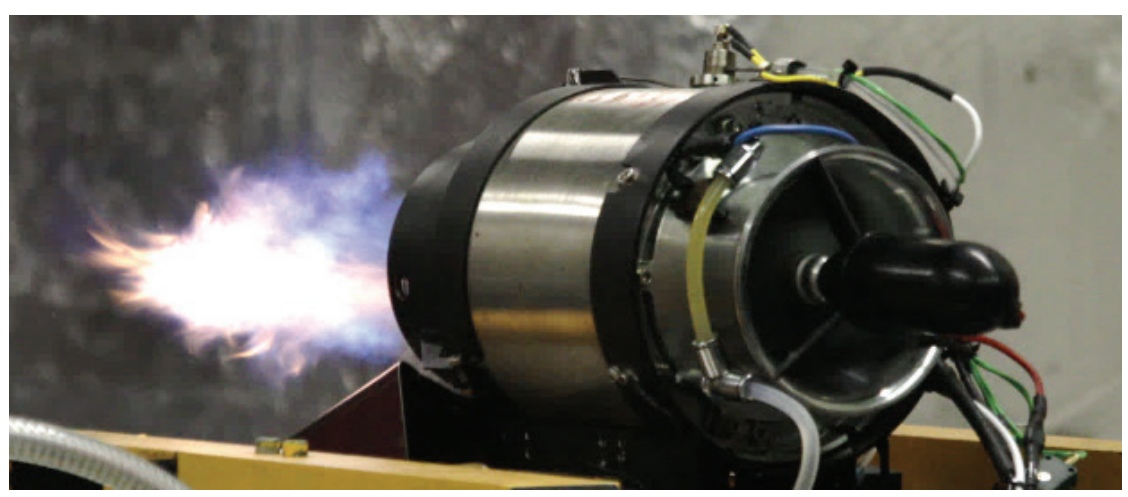

Fig. 1: TBS400N-TJ42 Jet engine

Ing. Jiří Matějů.: Institute of Aerospace Engineering, Brno University of Technology, Technická 2896/2; 616 69, Brno; CZ, mateju@fme.vutbr.cz 
HpH $304 \mathrm{~S}$ JET is high performance single seat flap glider with; $18 \mathrm{~m}$ wing span, $6.8 \mathrm{~m}$ fuselage length, empty weight $300 \mathrm{~kg}$ and maximum take of weight $600 \mathrm{~kg}$ (including $240 \mathrm{l}$ of water ballast for higher best glide speed). Stall speed is $88 \mathrm{~km} \cdot \mathrm{h}^{-1}$ at $600 \mathrm{~kg}$, the best glide ratio is more than 50 at $125 \mathrm{~km} \cdot \mathrm{h}^{-1}$ and maximum speed is $280 \mathrm{~km} \cdot \mathrm{h}^{-1}$. The thermal resistance of the composite tail part of the motor-less glider was $60{ }^{\circ} \mathrm{C}$, but it is possible to increase it to $80{ }^{\circ} \mathrm{C}$ by hardening process on the temperature $105^{\circ} \mathrm{C}$ for 15 hours.

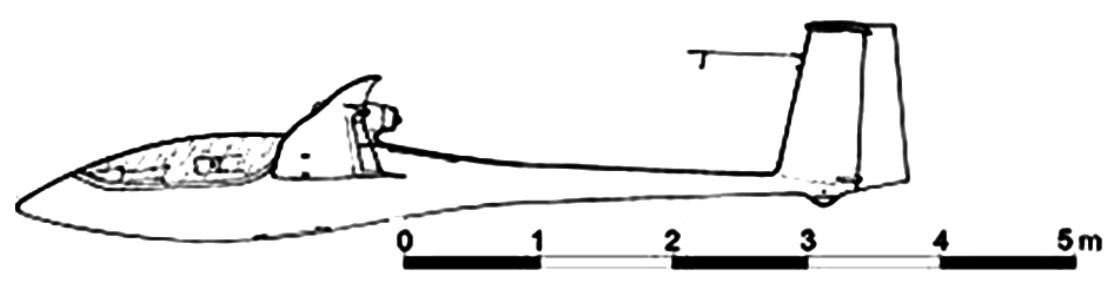

Fig. 2: HpH 304 S JET glider

\section{Experiment description}

Three temperature fields were tested at $1.3 \mathrm{~m}, 2 \mathrm{~m}$ and $3 \mathrm{~m}$ distances behind engine. Nine K-type vertically placed thermocouples (see fig. 3) were manually shifted in horizontal direction perpendicular to the engine axis.

Several problems were necessary to solve:

Low-cost quality testing was required. That is why testing facility (fig. 3) was manually operated and made in our laboratories (Juračka, 2017). Moving part of testing facility was made of aluminum bars. Infra-red radiation protection was made of concrete - glass fiber panel. Aluminum bars were not stiff enough and aeroelastic vibrations were too high, that is why fixing of aluminum bars was necessary.

No special engine operation was required, because certification process of an engine required tens hours of reliability tests (Matějů, 2018). These reliability tests were used for temperature field testing.

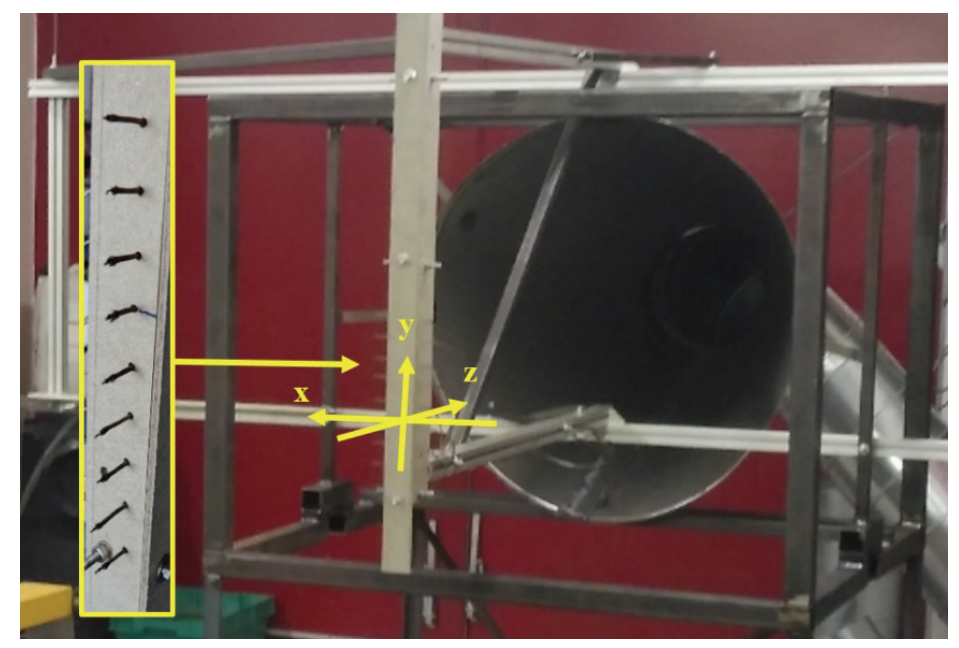

Fig. 3: Manually operated 1 axis traverse system with 9 K-type thermocouples (Kreidl, 2005) combined with suction device. (Thermocouples in concrete - glass fiber panel can be seen in detail).

Jet engine exhaust gasses smell more in comparison to larger jet engines, because engine combustion is incomplete and engine efficiency is relatively low. More over Jet-A1 fuel had to be mixed with $5 \%$ of AeroShell Turbine Oil. That is why only necessary tests could be finished.

The temperature on the tail was also examined during the flight tests, but only maximum temperature on the most exposed parts of the rudder (leading edge) was measured. The temperature was $20^{\circ} \mathrm{C}$ lower than during static tests. It is probably due to higher flow velocity and heat conduction in the tail. 


\section{Results}

Conditions of experiment are presented in tab. 2, (Matějů, 2017). Suction device for exhaust gases created parasitic flow velocity from 5 to $20 \mathrm{~km} / \mathrm{h}$. Unfortunately, this effect was not possible to eliminate.

Tab. 2: Conditions of experiments

\begin{tabular}{llccc}
\hline Position behind the engine & $(\mathrm{m})$ & 1,3 & 2 & 3 \\
\hline Indicated atmosphere temperature & $\left({ }^{\circ} \mathrm{C}\right)$ & 15 & 16 & 16 \\
\hline Atmospheric pressure & $(\mathrm{hPa})$ & 987 & 985 & 987 \\
\hline Parasitic flow velocity & $(\mathrm{km} / \mathrm{h})$ & $5-20$ & $5-20$ & $5-20$ \\
\hline
\end{tabular}

Reliability experiments is composed of four minutes group of cycles. Traverse system was manual and operator cannot move traverse system continually. Temperature is therefore measured on one horizontal position of nine thermocouples during whole group of cycles. Fig. 4 shows temperature-time dependency of the thermocouple with the highest maximum temperature at $3 \mathrm{~m}$ behind the engine.

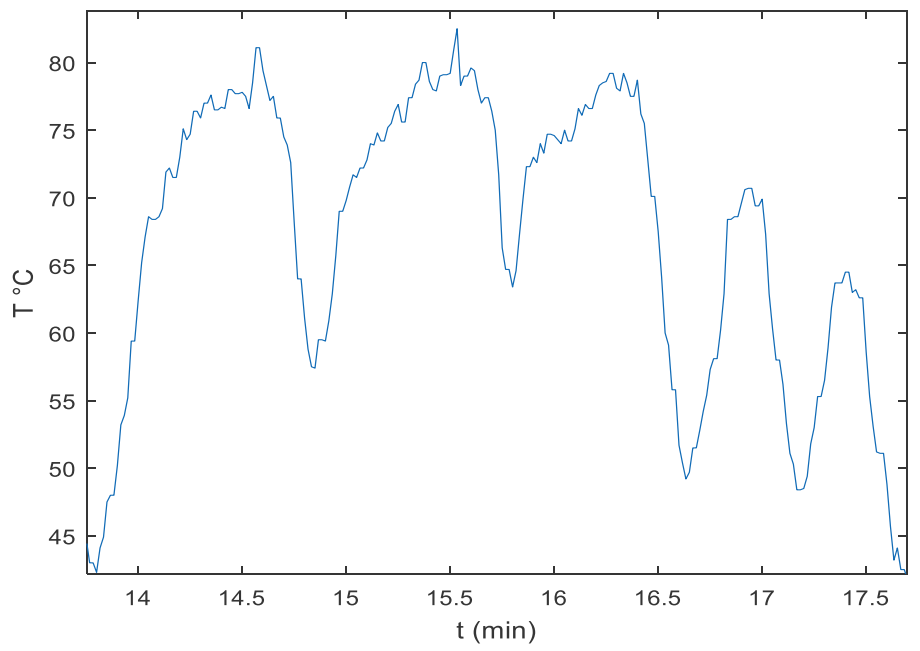

Fig. 4: Temperature-time dependency of one group of cycles.

Fig. 5, 6 and 7 show the maximum temperature distribution at $100 \%$ RPM measured during experiments. Maximum temperature of $182{ }^{\circ} \mathrm{C}$ was found at $1.3 \mathrm{~m}$ behind the engine, $121{ }^{\circ} \mathrm{C}$ at $2 \mathrm{~m}$ and $82^{\circ} \mathrm{C}$ at $3 \mathrm{~m}$. The results can be used for validation of simulation, even if some unavoidable uncertainties due to suction device and parasitic flow must be taken in account.

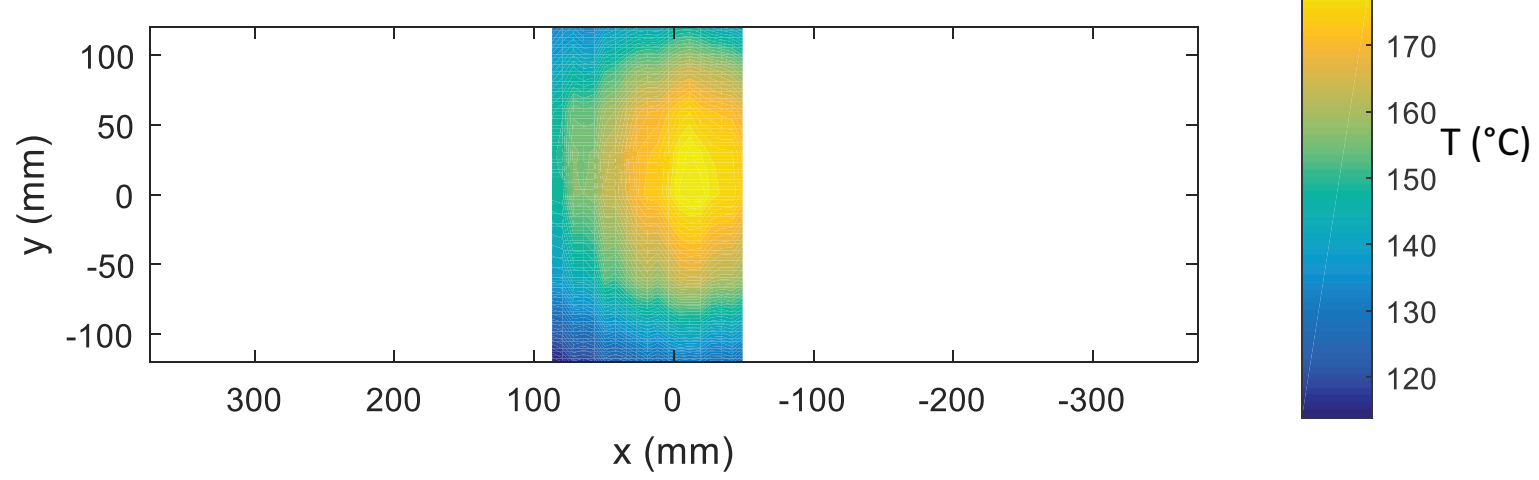

Fig. 5: Maximum temperature distribution at $100 \%$ RPM, $2 \mathrm{~m}$ behind the engine. 


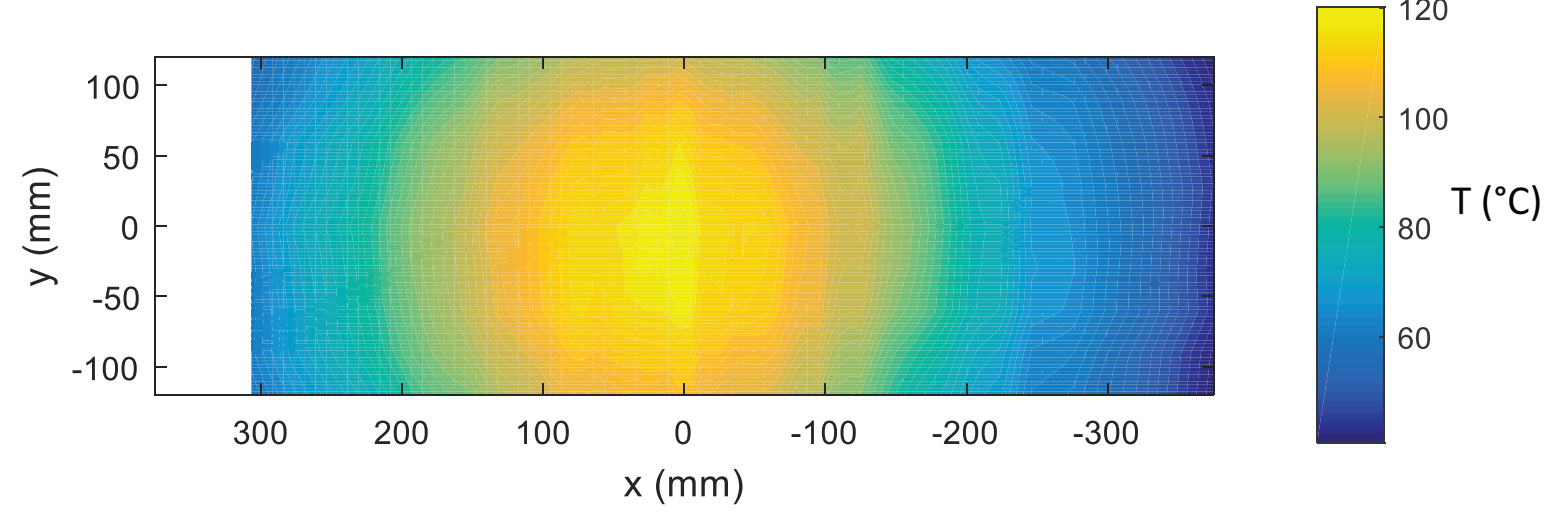

Fig. 6: Maximum temperature distribution at $100 \%$ RPM, $2 \mathrm{~m}$ behind the engine.
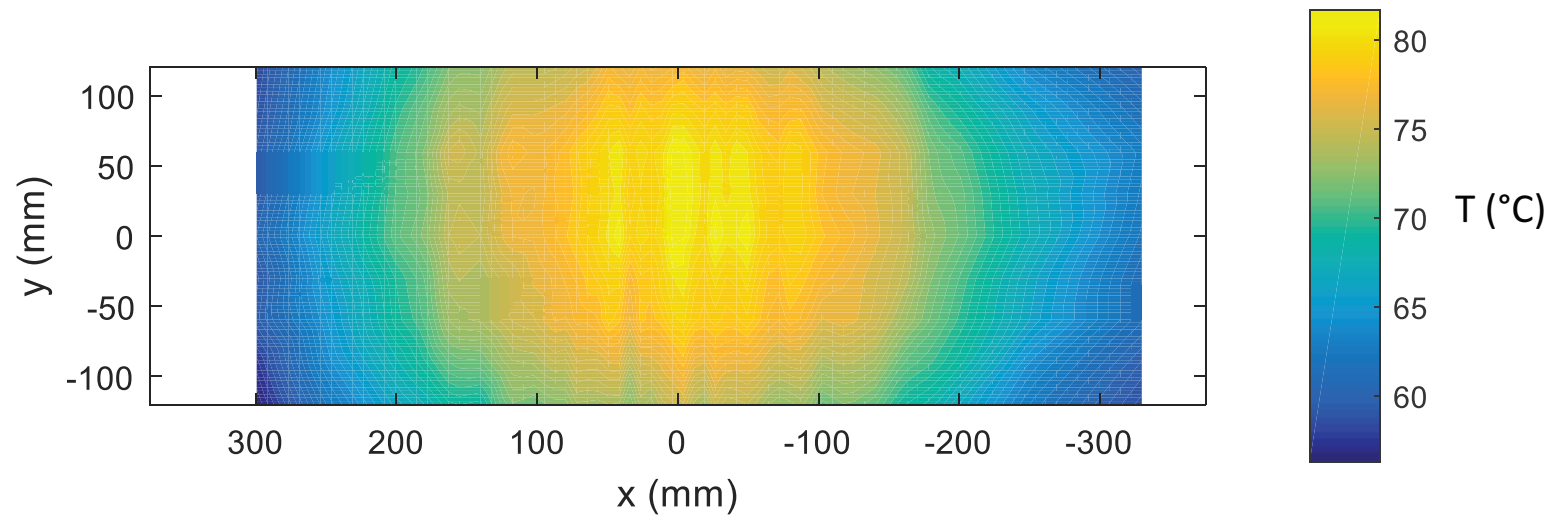

Fig. 7: Maximum temperature distribution at $100 \%$ RPM, $3 \mathrm{~m}$ behind the engine.

\section{Conclusions}

Results of temperature field measurement behind the glider jet engine at $1.3 \mathrm{~m}, 2 \mathrm{~m}$ and $3 \mathrm{~m}$ is presented. Experiment proved lower temperature than $85{ }^{\circ} \mathrm{C}$ at $3 \mathrm{~m}$ behind the engine, where the tail of the glider is influenced by hot exhaust gases. The high number of flight tests, finished by $\mathrm{HpH}$ s. r. o. company, showed even smaller maximum temperature of $65{ }^{\circ} \mathrm{C}$ in the tail part. This could be caused by higher velocity of air stream during flights and heat conduction in composite material. A technology of composite tail production was modified according to these results. Static ground tests, of the engine, is limited to 1 minute and static ground test at $100 \%$ RPM is limited to $4 \mathrm{~s}$.

\section{Acknowledgement}

The research leading to these results has received funding from the Ministry of Education, Young and Sport under the National Sustainability Programme I (Project LO1202).

\section{References}

Juračka, J. (2017) Specifics of Aerostructures Experimental Testing. In: Engineering Mechanics 2017, Brno University of Technology, Brno, pp. 46-49.

Kreidl, M. (2005) Měreni teploty: senzory a měřici obvody. Praha: BEN, 239 pg. ISBN 80-7300-145-4.

Matějů, J. (2017) Analýza teplotního pole za proudovým motorem kluzáku HpH 304 S JET, internal report LU662017-HpH.ZK, 12 pg.

Matějů; J. (2018) Zkoušky spolehlivosti motoru TJ-42 pro kluzák HpH 304 S JET, internal report LU01-2018HpH.ZK, 9 pg. 